\title{
PENGARUH STATUS SOSIAL EKONOMI ORANG TUA TERHADAP PRESTASI BELAJAR EKONOMI DAN PERILAKU KONSUMSI SISWA
}

\author{
Yahya Reka Wirawan, IKIP PGRI Madiun \\ reka_wan@yahoo.com
}

\begin{abstract}
ABSTRAK
Penelitian ini bertujuan untuk menganalisis pengaruh status sosial ekonomi orang tua terhadap prestasi belajar ekonomi dan perilaku konsumsi siswa. Sampel dalam penelitian ini adalah siswa jurusan IPS di SMA Negeri Kota Jombang Tahun Ajaran 2013/2014 sebanyak 155 orang dengan teknik propotional random sampling. Adapun teknik pengumpulan data yang digunakan yaitu data angket dan dokumentasi. Sedangkan metode analisis menggunakan teknik Structural Equation Modeling (SEM). Hasil penelitian menunjukkan bahwa status sosial ekonomi orang tua berpengaruh signifikan terhadap prestasi belajar ekonomi. Status sosial ekonomi orang tua berpengaruh signifikan terhadap perilaku konsumsi siswa. Begitu juga dengan prestasi belajar ekonomi berpengaruh signifikan terhadap perilaku konsumsi siswa.
\end{abstract}

Kata kunci: Status Sosial Ekonomi Orang Tua, Pretasi Belajar Ekonomi, Perilaku Konsumsi.

\begin{abstract}
This study aimed to analyze the influence of socio-economic status of parents on the learning achievement of economic and consumption behaviors of students. The sample in this study were students majoring in sosial studies in high school Jombang City Year 2013/2014 as many as 155 people with a proportional random sampling technique. The data collection techniques used are questionnaire and documentation. The results showed that the socioeconomic status of the parents have a significant effect on economics learning achievement. Socio-economic status of parents significantly influence consumption behavior of students. So also with the economic study achievement significantly influence consumption behavior of students.

Keywords : Socio-Economic Status of Parents, Economics Learning Achievement, Consumption Behavior
\end{abstract}

\section{PENDAHULUAN}

Suatu kehidupan manusia tidak terlepas dari suatu aspek ekonomi, dimana merupakan roda utama dalam menjalankan proses kehidupan di dunia ini. Pada dunia pendididikan di SMA (Sekolah Menengah Atas) yang merupakan salah satu tempat pendidikan untuk dapat mengembangkan kemampuan yang dimiliki individu baik dalam segi kognitif, afektif, maupun psikomotorik melalui proses pembelajaran yang dilakukan di sekolah khususnya mata pelajaran ekonomi.

Prestasi belajar menurut Suryabrata (2006) mendefinisikan bahwa nilai yang merupakan bentuk perumusan akhir yang diberikan oleh guru yang terkait dengan kemajuan prestasi belajar siswa selama periode waktu tertentu. Menurut Rifa'i 
dan Catharina (2006) prestasi belajar merupakan perubahan perilaku yang diperoleh pembelajaran setelah mengalami aktivitas belajar. Menurut Schiffman dan Kanuk (2008) bahwa perilaku seseorang dipengaruhi oleh kebutuhan, keinginan, hasrat yang belum terpenuhi, dan pengalaman belajar, serta kesadaran yang dimiliknya.

Hal inilah yang dimakasud dalam penelitian ini adalah prestasi belajar ekonomi. Jika siswa memiliki pengalaman belajar ekonomi yang optimal, maka siswa mampu berperilaku konsumsi yang bijak dan rasional. Sesuai dengan Supriya (2009) bahwa mata pelajaran ekonomi bertujuan agar peserta didik memiliki beberapa kemampuan yang diantaranya memamahami sejumlah konsep ekonomi untuk mengaitkan peristiwa dan masalah ekonomi dengan kehidupan sehari-hari terutama yang terjadi di lingkungan individu, rumah tangga, masyarakat, dan negara, menampilkan sikap ingin tahu pada sejumlah konsep ekonomi yang diperlukan untuk mendalami imu ekonomi, membentuk sikap bijak rasional dan bertanggung jawab dengan memiliki pengetahuan dan ketrampilan ilmu ekonomi, manajemen, dan akuntansi yang bermanfaat bagi diri sendiri, rumah tangga, masyarakat, dan negara, membuat keputusan yang bertanggung jawab mengenai nilai-nilai sosial ekonomi dalam masyarakat majemuk baik skala nasional maupun internasional

Dalam proses kegiatan belajar mengajar, siswa dan guru diharapkan mampu memberikan bekal kepada siswa untuk memiliki kemampuan di bidang ekonomi, sehingga siswa mampu berperilaku ekonomi secara rasional. Pada penerapan kurikulum 2013, berbagai lulusan sekolah, peserta didik dituntut memiliki kecakapan hidup untuk membentuk sikap dan perilaku yang rasional terutama dalam pengambilan keputusan untuk berperilaku konsumsi.

Fenomena umum yang terjadi pada peserta didik, dimana masa remaja yang masih mencari jati diri dan belum mempunyai dasar atau prinsip dalam berperilaku konsumsi. Belum adanya dasar atau prinsip yang kuat dalam berkonsumsi, mengarahkan siswa untuk berperilaku konsumtif. Perilaku konsumsi dalam pandangan masyarakat secara umum adalah suatu kajian tentang bagaimana seseorang membeli atau melakukan konsumsi atas suatu produk.

Menurut Kotler dan Amstrong (2012), perilaku konsumsi dapat diartikan sebagai perilaku pembelian akhir, baik individu maupun rumah tangga, yang membeli produk untuk konsumsi personal. Menurut Chaney (2003) mendefinisikan konsumsi adalah seluruh tipe aktifitas sosial yang orang lakukan sehingga dapat dipakai untuk mencirikan dan mengenal mereka, selain sebagai tambahan apa yang mungkin mereka lakukan untuk hidup. Kemudian menurut Samuelson (2000) menjelaskan bahwa konsumsi adalah kegiatan menghabiskan nilai guna barang dan jasa.

Hasil survei pada Februari hingga awal Maret 2013 menempatkan Indonesia ke posisi teratas negara yang penduduknya paling optimistis dalam memanfaatkan uang. Dalam hal belanja, Indonesia diibaratkan sebagai mal raksasa, di mana di dalamnya ditawarkan berbagai barang konsumsi dan hampir semuanya terserap oleh pasar. Hal ini dibarengi dengan kecenderungan bahwa konsumen Indonesia lebih mengutamakan membeli barang untuk style (penampilan) dibandingkan dengan utility (kegunaan). Itu terjadi terutama pada barang konsumsi yang tergolong fast moving consumer goods. Konsumen pada tipe produk cepat laku seperti ini dengan mudah berganti ponsel dalam waktu singkat atau mengejar 
gadget terbaru sambil melihat daftar produk lain secara online maupun offline. Survey tersebut menunjukkan bahwa rata-rata ABG berperilaku konsumsi. Maka, upaya yang bisa dilakukan dalam rangka mengarahkan perilaku konsumsi siswa adalah melalui pembelajaran atau penyampaian materi mata pelajaran ekonomi terutama materi yang mendasari perilaku konsumsi siswa (Amaldoss, 2002)

Temuan hasil survey tersebut sejalan dengan apa yang dikemukakan oleh Wells dan Presky (2008), dimana perilaku konsumsi siswa berlatar pada motivasi dan proses kognitif. Motivasi yang mendasari perilaku konsumsi siswa adalah motif aktualisasi diri dan kebutuhan fisiologis. Pada usia remaja motif aktualisasi diri memegang peranan yang penting, motif ini terkadang membuat siswa mengabaikan aspek rasionalitas. Siswa cenderung terdorong untuk membeli barang-barang yang trend untuk fungsi aktualisasi diri, dan tidak mementingkan bagaimana fungsi dan manfaat barang yang akan dikonsumsi.

Perilaku konsumsi di SMA Negeri di kota Jombang dapat diketahui bahwa peserta didik memiliki kecenderungan untuk suka mengkonsumsi barang-barang yang sangat bagus daripada nilai kegunaannya, dimana dilihat dari segi uang saku peserta didik rata-rata cukup umtuk memenuhi kebutuhan-kebutuhan style atau penampilan yang sangat berkelas. Semisal saja yang trend saat ini, yakni sebuah gadget yang diantaranya handphone berbasis android, tablet, smartphone yang canggih, notebook atau netbook (laptop) apabila dilihat dari segi utility bagi pelajar kurang cocok untuk dipakai dalam aktivitas belajar peserta didik.

Sebagian perilaku peserta didik remaja banyak menghabiskan waktu hanya untuk hiburan semata dibandingkan dengan urusan akademik. Ketika seorang peserta didik tidak dapat memanfaatkan waktu yang baik, sering mengulur waktu dengan melakukan kegiatan yang tidak bermanfaat, sehingga waktu terbuang siasia. Akibatnya tugas-tugas dalam belajar terbengkalai dan tidak maksimal dalam menyelesaikannya, sehingga dapat berpotensi terhambatnya untuk meraih kesuksesan ata prestasi belajar yang optimal.

Hal ini dipengaruhi oleh status sosial ekonomi orang tua siswa, dimana orang tua yang dalam kategori mampu atau kaya akan memberikan uang saku yang banyak dan berlebihan, sehingga siswa akan merasa terpenuhi untuk membeli segala sesuatu yang diinginkan. Rasa puas dan senang tentunya dimiliki oleh siswa itu sendiri yang terkadang bagi siswa yang status sosial ekonomi orang tuanya rendah merasa iri.

Berdasarkan data dari SMA Negeri sekota Jombang, 659 peserta didik yang status sosial ekonomi orang tuanya berkategori tinggi sebanyak 530 siswa $(80,42 \%)$, dalam kategori sedang sebanyak 102 siswa $(15,47 \%)$, dan dalam kategori rendah sebanyak 27 siswa $(4,1 \%)$. Status sosial ekonomi mempunyai peranan terhadap perkembangan seseorang termasuk pada aspek ekonominya khususnya perilaku konsumsi dengan kata lain status sosial ekonomi orang tua akan menentukan tingkat pengalaman dalam kehidupan sehari-hari tidak terkecuali siswa, yang mana dilihat dari gaya hidup siswa dalam mengonsumsi suatu barang terlihat jelas terdapat perbedaan yang cukup dominan yang menunjukan status sosial ekonominya.

Hal ini sejalan pada penelitian menurut Chang, et.al. (2008) bahwa status sosial ekonomi keluarga atau orang tua berpengaruh signifikan terhadap perilaku konsumsi, dimana juga berpengaruh positif terhadap prestasi. Status sosial ekonomi mempengaruhi prestasi belajar, dimana hal ini sejalan pada penelitian 
menurut Engweiler (2005) bahwa pengaruh yang paling kuat pada prestasi belajar siswa adalah status sosial ekonomi. Sedangkan, menurut Mehmood (2011) bahwa status sosial ekonomi pada sebuah keluarga berdampak pada prestasi belajar siswa melalui berbagai macam cara, dimana pendidikan dari orang tua yang cocok ditanamkan pada anak-anak melalui berbagai fasilitas dan teknologi yang mendukung.

Menurut Soekanto (2003) status sosial ekonomi adalah posisi seseorang dalam masyarakat berkaitan dengan orang lain dalam arti lingkungan pergaulan, prestasinya, dan hak-hak serta kewajibannya dalam hubunganya dengan sumber daya. Menurut Coleman \& Cressey dalam Sumardi (2004) tingkatan status sosial ekonomi terdiri dari: a) Status sosial ekonomi atas; dan b) Status sosial ekonomi bawah. Status sosial ekonomi atas adalah status sosial atau kedudukan seseorang di masyarakat yang diperoleh berdasarkan penggolongan menurut kekayaan, di mana harta yang dimiliki di atas rata-rata masyarakat pada umumnya dan dapat memenuhi kebutuhan sehari-hari dengan baik. Status sosial ekonomi bawah adalah kedudukan seseorang di masyarakat yang diperoleh berdasarkan penggolongan menurut kekayaan, dimana harta kekayaan yang dimiliki termasuk kurang jika dibandingkan dengan rata-rata masyarakat pada umumnya serta tidak mampu dalam memenuhi kebutuhan hidup sehari-hari.

Indikator variabel yang digunakan untuk mengukur status sosial ekonomi orang tua dari definisi yang diberikan Schiffman (2008) dan Solomon (2006) terdiri dari: a) latar belakang pendidikan orang tua, yang merupakan pendidikan akademik terakhir dari ayah, b) pekerjaan orang tua, yang merupakan mata pencaharian ayah dalam kehidupan untuk memenuhi kebutuhan sehari-hari, dan c) penghasilan orang tua, yang merupakan pendapatan dari mata pencaharian ayah.

Tu'u (2004) mendefinisikan prestasi belajar sebagai hasil yang dicapai seseorang ketika mengerjakan tugas atau kegiatan tertentu. Sementara menurut Tu'u prestasi belajar adalah penguasaan pengetahuan atau keterampilan yang dikembangkan oleh mata pelajaran. Prestasi belajar siswa banyak dipengaruhi oleh berbagai faktor baik berasal dari dirinya (intern) maupun dari luar dirinya (ekstern). Menurut Slameto (2010) faktor-faktor yang mempengaruhi prestasi belajar adalah sebagai berikut: a) Faktor Intern, meliputi faktor jasmaniah (fisiologi), faktor psikologis, dan faktor kelelahan; b) Faktor Ekstern, meliputi faktor keluarga, faktor sekolah, dan faktor masyarakat. Indikator yang digunakan untuk mengukur prestasi belajar ekonomi diambil dari nilai rapot semester, yang terdiri dari nilai ulangan harian, ujian tengah semester, dan ujian akhir semester.

Menurut Mowen (2002) perilaku konsumsi (consumption behaviour) didefinisikan sebagai studi tentang unit pembelian (buying units) dan proses pertukaran yang melibatkan perolehan, konsumsi dan pembuangan barang, jasa, pengalaman serta ide-ide. Sedangkan Perilaku konsumsi siswa merupakan suatu bentuk aktivitas atau tindakan yang dilakukan siswa untuk memenuhi kebutuhan untuk membeli atau melakukan suatu konsumsi produk. Indikator yang digunakan untuk mengukur perilaku konsumsi dari definisi yang diberikan Erich Fromm (1995) terdiri dari: a) pemenuhan kebutuhan sesuai intensitas, b) penerapan prinsip ekonomi dalam konsumsi, dan c) motif ekonomi dalam konsumsi.

Pentingnya penelitian ini dilakukan untuk mengkaji lebih dalam tentang: a) pengaruh status sosial ekonomi orang tua terhadap prestasi belajar ekonomi, b) 
pengaruh status sosial ekonomi orang tua terhadap perilaku konsumsi siswa, serta c) pengaruh prestasi belajar ekonomi terhadap perilaku konsumsi siswa.

\section{METODE PENELITIAN}

Pendekatan yang digunakan dalam penelitian ini adalah pendekatan kuantitatif sedangkan variabel dalam penelitian ini adalah status sosial ekonomi orang tua sebagai variabel independen sedangkan prestasi belajar ekonomi dan perilaku konsumsi siswa sebagai variabel dependen. Populasi dalam penelitian ini seluruh siswa kelas XI dan XII IPS SMA Negeri di Kota Jombang yang berjumlah 659 siswa. Sampel penelitian sebesar 155 siswa. Teknik sampling yang digunakan teknik propotional random sampling.

Metode pengumpulan data yang digunakan dalam penelitian ini adalah kuesioner dan dokumentasi. Teknik analisis data yang digunakan dalam penelitian ini adalah SEM (Structural Equation Modelling). Spesifikasi model antar variabel digambarkan pada gambar dibawah ini.

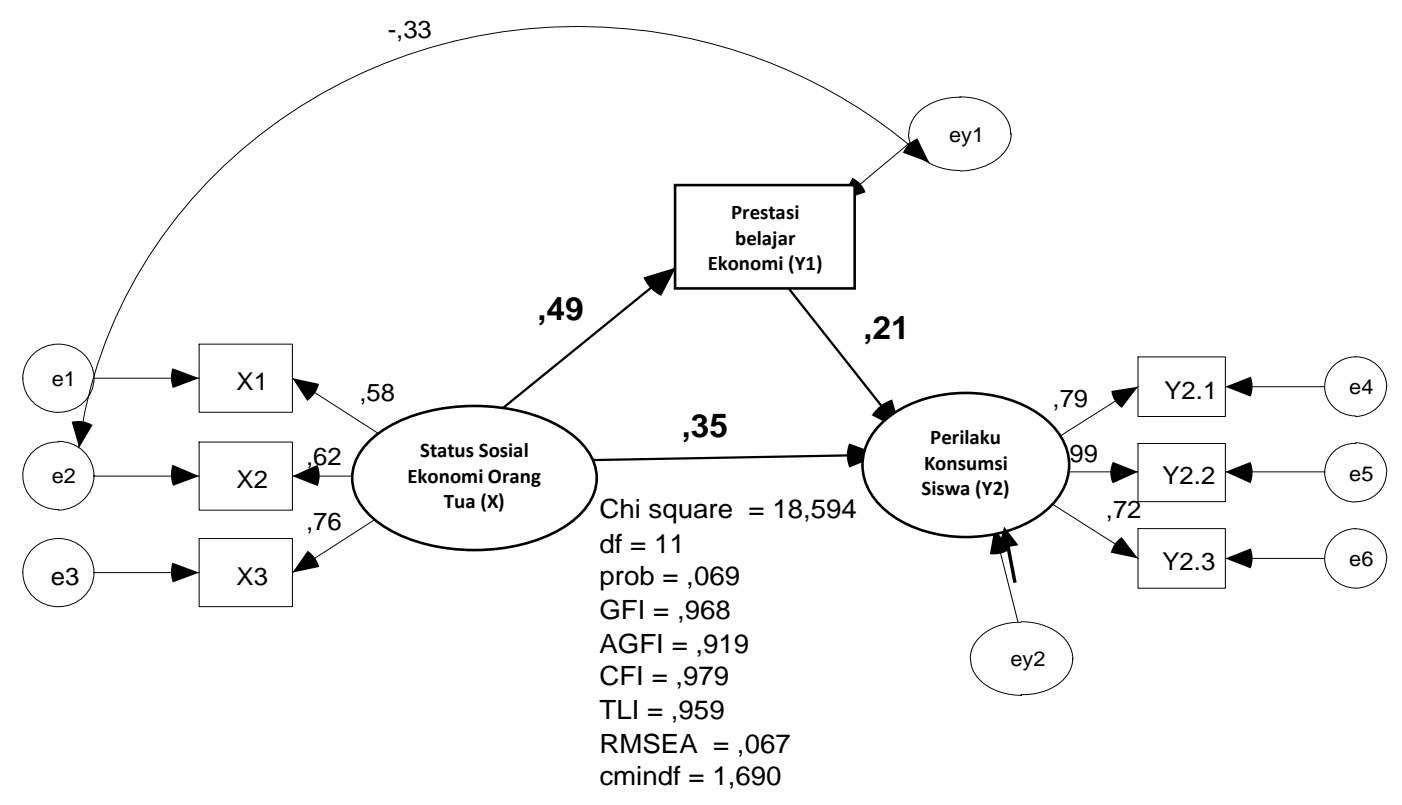

Gambar 1. Model Antar Variabel

\section{HASIL DAN PEMBAHASAN}

Hasil uji Goodness Of Fit Index dengan nilai $X^{2}$-chi-square nilai 18,594, Significant Probability 0,069 $\geq 0,05$, CMIN/DF 1,690 $\leq 2,00$, GFI 0,968 $\geq 0,90$, AGFI $0,919 \geq 0,90$, TLI $0,959 \geq 0,95$, CFI 0,979 $\geq 0,95$, RMSEA $0,000 \leq 0,08$ Berdasarkan uji goodness of fit disimpulkan model dapat diterima, hipotesis nol yang menyatakan tidak terdapat perbedaan matriks kovarians sampel dan matriks kovarians populasi yang diestimasi diterima.

Berdasarkan hasil goodness of fit index dapat diketahui bahwa seluruh 
parameter Chi square, probabilitas error, GFI, AGFI, TLI, CFI dan RMSEA sudah memenuhi syarat batas ambang yang direkomendasikan oleh AMOS.

Tabel 1. Uji Hipotesis

\begin{tabular}{|l|l|l|l|l|}
\hline No & Variabel & Koefisien & C.R. & Keterangan \\
\hline 1. & $\begin{array}{l}\text { Status Sosial Ekonomi Orang } \\
\text { Tua }(\mathrm{X}) \rightarrow \text { Prestasi Belajar } \\
\text { Ekonomi }\left(\mathrm{Y}_{1}\right)\end{array}$ & 0,489 & 2,766 & Signifikan \\
\hline 2 & $\begin{array}{l}\text { Status Sosial Ekonomi Orang } \\
\text { Tua }(\mathrm{X}) \rightarrow \text { Perilaku Konsumsi } \\
\text { Siswa (Y) }\end{array}$ & 0,355 & 2,414 & Signifikan \\
\hline 3 & $\begin{array}{l}\text { Prestasi Belajar Ekonomi (Y) } \\
\rightarrow \text { Perilaku Konsumsi Siswa } \\
\left(Y_{2}\right)\end{array}$ & 0,211 & 2,169 & Signifikan \\
\hline
\end{tabular}

Sumber: Data Diolah (2014)

Berdasarkan tabel diatas diperoleh hasil sebagai berikut: 1) Hipotesis satu $\left(\mathrm{H}_{1}\right)$ menyatakan bahwa status sosial ekonomi orang tua berpengaruh terhadap prestasi belajar ekonomi. Koefisien jalur yang bertanda positif sebesar 0,489 dengan nilai C.R. sebesar 2,766 lebih besar dari 1,96, artinya status sosial ekonomi orang tua berpengaruh terhadap prestasi belajar ekonomi. 2) Hipotesis dua $\left(\mathrm{H}_{2}\right)$ menyatakan bahwa status sosial ekonomi orang tua berpengaruh terhadap perilaku konsumsi siswa. Koefisien jalur yang bertanda positif sebesar 0,355 dengan nilai C.R. sebesar 2,414 lebih besar dari 1,96, artinya status sosial ekonomi oorang tua berpengaruh terhadap perilaku konsumsi siswa. 3) Hipotesis tiga $\left(\mathrm{H}_{3}\right)$ menyatakan bahwa prestasi belajar ekonomi berpengaruh terhadap perilaku konsumsi siswa. Koefisien jalur yang bertanda positif sebesar 0,211 dengan nilai C.R. sebesar 2,169 lebih besar dari 1,96, artinya prestasi belajar ekonomi berpengaruh terhadap perilaku konsumsi siswa.

Pengujian hipotesis tidak langsung status sosial ekonomi orang tua terhadap perilaku konsumsi siswa melalui prestasi belajar ekonomi dilakukan dengan uji Sobel (Preacher, 2004) dengan rumus sebagai berikut.

$$
\begin{aligned}
\mathrm{tXY} & =\frac{\text { koefisian } X Y 1 \times \text { kogfisien } Y 1 Y_{2}}{\sqrt{\left(X Y 1^{2} S_{Y_{1} Y_{2}}^{2}\right)+\left(Y 1 Y_{2}^{2} \cdot S_{X Y_{1}}^{2}\right)+\left(S_{Y_{1} Y_{1}}^{2} S_{X Y_{1}}^{2}\right)}} \\
& =\frac{0,489 \times 0,211}{\sqrt{\left(0,489^{2} \times 0,005^{2}\right)+\left(0,211^{2} \times 2,455^{2}\right)+\left(0,005^{2} \times 2,455^{2}\right)}} \\
& =\frac{0,1032}{1,460}=0,071
\end{aligned}
$$

Sumber: data diolah (2014)

Hasil t hitung koefisien tidak langsung sebesar $0,071<$ nilai $\mathrm{Z}$ test $(1,96)$ menunjukkan bahwa koefisien tidak langsung jalur status sosial ekonomi orang tua $(\mathrm{X})$ terhadap perilaku konsumsi siswa $\left(\mathrm{Y}_{2}\right)$ melalui prestasi belajar ekonomi $\left(\mathrm{Y}_{1}\right)$ sebesar 0,071 tidak signifikan. 


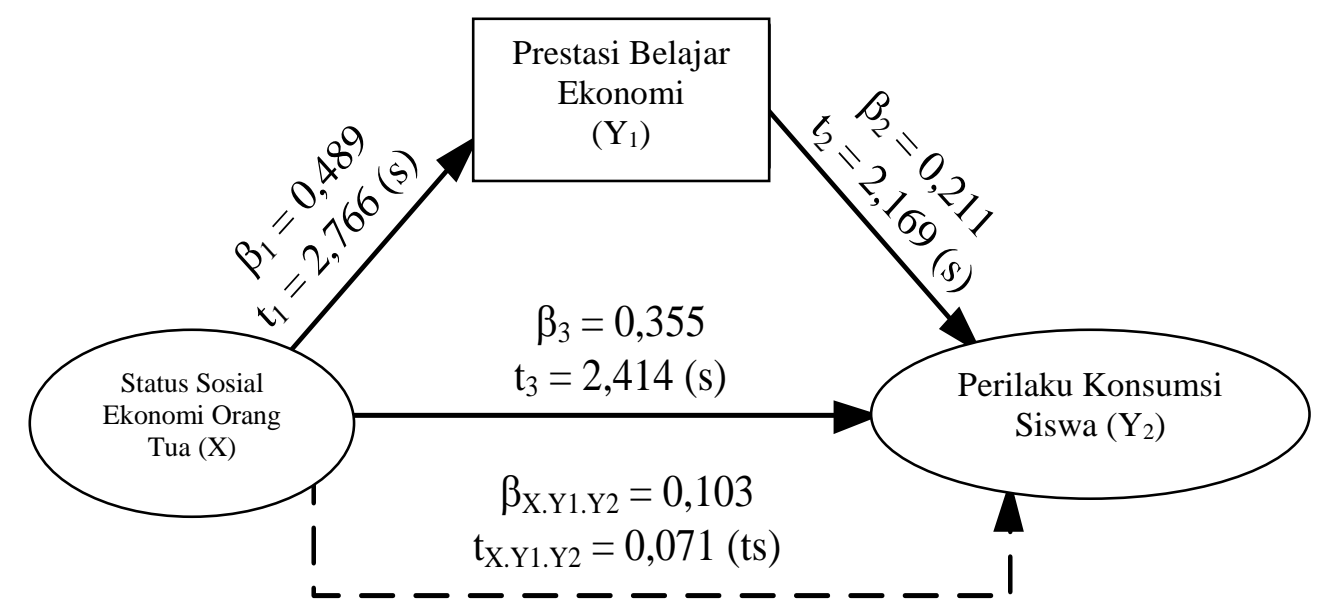

Gambar 2. Model Pengaruh Tidak Langsung Status Sosial Ekonomi Orang Tua terhadap Perilaku Konsumsi Siswa melalui Prestasi Belajar Ekonomi

Berdasarkan hasil analisis persamaan model struktural pertama, menunjukkan bahwa terdapat pengaruh status ekonomi terhadap prestasi belajar. Hasil penelitian ini mendukung hasil penelitian Soekanto (2003) yang menyatakan Status sosial ekonomi orangtua sangat berdampak bagi pemenuhan kebutuhan keluarga dalam mencapai standar hidup yang sejahtera dan mencapai kesehatan yang maksimal.

Status sosial ekonomi atas adalah status atau kedudukan seseorang di masyarakat yang diperoleh berdasarkan penggolongan menurut peghasilan (Sitorus, 2000). Pada penelitian ini penghasilan ayah dan ibu dibagi ke dalam empat kategori yaitu: 1) sangat tinggi ( $\geq$ Rp3.500.000,00); 2) Tinggi (Rp2.500.000,00 s.d. Rp3.500.000,00; 3) Sedang (Rp1.500.000,00 s.d. $\mathrm{Rp2} .500 .000,00)$; dan 4) rendah ( $\leq \mathrm{Rp} 1.500 .000,00)$.

Berdasarkan empat kategori penghasilan tersebut di atas dapat diketahui bahwa secara berurutan dari yang paling banyak jumlahnya sampai yang paling sedikit yaitu: 1) Tinggi (Rp2.500.000,00 s.d. Rp3.500.000,00); 2) Sedang (Rp1.500.000,00 s.d. Rp2.500.000,00); 3) sangat tinggi ( $\geq$ Rp3.500.000,00); 2) Tinggi (Rp2.500.000,00 s.d. Rp3.500.000,00; 4) rendah ( $\leq$ Rp1.500.000,00).

Berdasarkan hasil analisis faktor konfirmatori status ekonomi orang tua siswa yang diindikatori oleh pendidikan ayah, pekerjaan ayah dan penghasilan ayah sudah dapat digunakan (fit) untuk menjelaskan konstruk status ekonomi. Pendidikan ayah terbanyak tamat SMA/SMK/MA/sederajat, sedangkan paling sedikit jumlahnya tamat SD dan atau tidak sekolah. Pekerjaan ayah terbanyak jumlahnya sebagai pengusaha, PNS, maupun guru/dosen. Penghasilan terbanyak sekitar Rp2.500.000,00 s.d. Rp3.500.000,00, sedangkan paling sedikit jumlahnya kurang dari Rp1.500.000,00.

Tingkat pendidikan orang tua yang baik, pendapatan ekonomi orang tua yang mencukupi dapat meningkatkan prestasi belajar ekonomi siswa. Dan 
sebaliknya siswa dengan orang tua status sosial ekonomi rendah relatif memiliki prestasi belajar ekonomi yang rendah pula.Hasil belajar yang baik tidak dapat diperoleh dengan hanya mengandalkan keterangan-keterangan yang diberikan oleh guru di depan kelas, tetapi membutuhkan jua alat-alat yang memadai seperti buku tulis, pensil, peta, pena dan terlebih dahulu lagi buku bacaan. Sebagian besar alat-alat pelajaran itu harus disediakan sendiri oleh murid-murid yang bersangkutan. Bagi orang tua yang keadaan ekonominya kurang memadai sudah barang tentu tidak dapat memenuhi kebutuhan-kebutuhan anaknya secara memuaskan. Apabila keadaan ini terjadi pada orang tua siswa, maka siswa yang bersangkutan akan menanggung resiko-resiko yang tidak diharapkan. Keluarga sangat berperan aktif bagi siswa dan dapat mempengaruhi dari keluarga antara lain: cara orang tua mendidik, relasi antara anggota keluarga, keadaan keluarga, pengertian orang tua, keadaan ekonomi keluarga, latar belakang kebudayaan dan suasana rumah.

Keluarga dengan pendapatan cukup atau tinggi pada umumnya akan lebih mudah memenuhi segala kebutuhan sekolah dan keperluan lain. Berbeda dengan keluarga yang mempunyai penghasilan relatif rendah, pada umumnya mengalami kesulitan dalam pembiayaan sekolah, begitu juga dengan keperluan lainnya. Selain itu juga didukung oleh temuan pada variable prestasi belajar ekonomi siswa SMA Negeri Kota Jombang, di mana dalam deskripsi responden atau nilai rapotnya sangat bagus dan tinggi. Hal ini menunjukkan bahwa sebagian besar prestasi belajar ekonomi siswa SMA Negeri Kota Jombang tergolong sangat baik dan tinggi.

Penelitian ini mendukung teori menurut Engweiler (2005) bahwa pengaruh yang paling kuat pada prestasi belajar siswa adalah status sosial ekonomi. Sedangkan, menurut Mehmood (2011) bahwa status sosial ekonomi pada sebuah keluarga berdampak pada prestasi belajar siswa melalui berbagai macam cara, dimana pendidikan dari orang tua yang cocok ditanamkan pada anak-anak melalui berbagai fasilitas dan teknologi yang mendukung. Dengan demikian dapat disimpulkan bahwa status sosial ekonomi orang tua terbukti dapat memberikan sumbangan positif terhadap tercapainya prestasi belajar ekonomi siswa yang tinggi dan terbukti dapat menjadi prediktor yang mempengaruhi prestasi belajar ekonomi pada siswa SMA Negeri Kota Jombang

Berdasarkan hasil analisis persamaan model struktural kedua, menunjukkan bahwa terdapat pengaruh status ekonomi terhadap konsumsi siswa. Hasil penelitian ini mendukung hasil penelitian Engel et al. (1994) bahwa tindakan yang langsung terlibat dalam mendapatkan, mengkonsumsi, dan menghabiskan produk dan jasa, termasuk proses yang mendahului dan menyusul dari tindakan ini.

Status sosial ekonomi orang tua berpengaruh pada perilaku konsumsi siswa. Bukti empiris mengindikasikan bahwa semakin tinggi status sosial ekonomi orang tua, maka semakin tinggi pula tingkat rasionalitas siswa dalam berkonsumsi. Dalam penelitian ini diketahui bahwa sebagian besar siswa memiᄀliki perilaku konsumsi yang kurang rasional. Dan status sosial ekonomi orang tua siswa sebagian besar adalah tergolong sedang. Temuan dalam penelitian ini sejalan dengan apa yang telah dikemukakan oleh Engel et al. (1994). Perilaku konsumsi siswa berlatar pada motivasi dan proses kognitif. Motivasi yang mendasari perilaku konsumsi siswa adalah motif aktualisasi diri dan kebutuhan fisi $\neg$ ologis. Diusia remaja motif aktualisasi diri memegang peranan yang penting, motif ini 
terkadang membuat siswa mengabaikan aspek rasionalitas. Siswa cenderung terdorong untuk membeli barang-barang yang sedang trend untuk fungsi aktualisasi diri, dan tidak mementingkan bagaimana fungsi dan manfaat barang yang akan dikonsumsi.

Status sosial ekonomi orang tua berpengaruh signifikan terhadap prestasi belajar ekonomi didukung oleh temuan pada variable status sosial ekonomi orang tua yang terdapat pada tiga indicator yaitu pendidikan orang tua, pekerjaan orang tua, dan penghasilan orang tua. Hasil temuan di SMA Negeri Kota Jombang menunjukkan bahwa tingkat pendidikan terbanyak tamat SMA/SMK/MA/ sederajat, sedangkan paling sedikit jumlahnya tamat SD dan atau tidak sekola. Pekerjaan ayah terbanyak jumlahnya sebagai pengusaha, PNS, guru/dosen. Penghasilan terbanyak sekitar Rp2.500.000,00 s.d. Rp3.500.000,00, sedangkan paling sedikit jumlahnya kurang dari Rp1.500.000,00. Dalam hal ini, pendidikan orang tua yang baik, pendapatan ekonomi orang tua yang mencukupi dapat meningkatkan prestasi belajar ekonomi siswa. Dan sebaliknya siswa dengan orang tua status sosial ekonomi rendah relatif memiliki prestasi belajar ekonomi yang rendah pula. prestasi belajar yang baik tidak dapat diperoleh dengan hanya mengandalkan keterangan-keterangan yang diberikan oleh guru di depan kelas, tetapi membutuhkan jua alat-alat yang memadai seperti buku tulis, pensil, peta, pena dan terlebih dahulu lagi buku bacaan. Sebagian besar alat-alat pelajaran itu harus disediakan sendiri oleh murid-murid yang bersangkutan. Bagi orang tua yang keadaan ekonominya kurang memadai sudah barang tentu tidak dapat memenuhi kebutuhan-kebutuhan anaknya secara memuaskan. Apabila keadaan ini terjadi pada orang tua siswa, maka siswa yang bersangkutan akan menanggung resiko-resiko yang tidak diharapkan. Keluarga sangat berperan aktif bagi siswa dan dapat mempengaruhi dari keluarga antara lain: cara orang tua mendidik, relasi antara anggota keluarga, keadaan keluarga, pengertian orang tua, keadaan ekonomi keluarga, latar belakang kebudayaan dan suasana rumah. Orang tua dengan pendapatan cukup atau tinggi pada umumnya akan lebih mudah memenuhi segala kebutuhan sekolah dan keperluan lain. Berbeda dengan keluarga yang mempunyai penghasilan relatif rendah, pada umumnya mengalami kesulitan dalam pembiayaan sekolah, begitu juga dengan keperluan lainnya.

Berdasarkan hasil analisis persamaan model struktural ketiga, menunjukkan bahwa terdapat pengaruh prestasi belajar terhadap konsumsi siswa. Semakin tinggi nilai ekonomi siswa maka semakin rasional pula pola perilaku konsumsi siswa. Pelajaran ekonomi merupakan salah satu mata pelajaran yang ruang lingkupnya mencakup perilaku konsumsi. Hasil penelitian ini mendukung hasil penelitian sebelumnya, yaitu penelitian yang dilakukan oleh Chang, et. al (2008) bahwa status sosial ekonomi keluarga atau orang tua berpengaruh signifikan terhadap perilaku konsumsi, dan juga berpengaruh positif terhadap prestasi belajar siswa, apa yang telah dipelajari oleh siswa secara langsung dapat diterapkan dalam kehidupannya. Hal ini juga dapat diartikan bahwa prestasi belajar yang yang dicapai oleh siswa tidak hanya nilai pelajaran ekonomi, melainkan juga berupa adanya perubahan sikap dan tingkah laku.

Selain itu penelitian yang dilakukan oleh Haryono (2008) menjelaskan bahwa kecakapan siswa SMA dalam menggunakan ilmu ekonomi dalam kehidupan sehari-hari atau dalam berperilaku konsumsi, masih sangat jauh dari harapan, sehingga diharapkan mata pelajaran ekonomi dapat lebih banyak 
memberikan tambahan pengetahuan yang mengarah pada pembentukan sikap untuk menjadikan siswa sebagai pelaku ekonomi yang efektif dan efisien berdasarkan pengalaman belajar yang diterimanya. Dengan demikian apa yang telah dipelajari oleh siswa SMA Negeri di Kota Jombang secara langsung dapat diterapkan dalam kehidupannya. Dengan demikian apa yang telah dipelajari oleh siswa secara langsung dapat diterapkan dalam kehidupannya. Hal ini juga dapat diartikan bahwa prestasi belajar yang yang dicapai oleh siswa tidak hanya nilai pelajaran ekonomi, melainkan juga berupa adanya perubahan sikap dan tingkah laku. Fakta dari penelitian ini menunjukkan bahwa siswa dengan prestasi belajar ekonomi yang tinggi atau memiliki kemampuan kognitif yang baik secara psikomotor juga memiliki kemampuan yang baik pula. Sebab siswa yang memiliki nilai ekonomi yang baik ia dapat menerapkan dengan baik pengetahuannya atau dalam hal ini dalam berperilaku konsumsi lebih bersifat rasional. Fenomena diatas merupakan beberapa penyebab mengapa seseorang yang prestasi belajarnya bagus tetapi tidak bisa dijadikan jaminan bahwa seorang siswa dengan hasil belajar yang baik mampu mengaplikasikan dalam situasi yang relevan dengan kehidupannya.

\section{KESIMPULAN}

Hasil penelitian menunjukkan bahwa: 1) Terdapat pengaruh signifikan status ekonomi terhadap prestasi belajar. Tingkat pendidikan orang tua yang baik, pendapatan ekonomi orang tua yang mencukupi dapat meningkatkan prestasi belajar ekonomi siswa. Dan sebaliknya siswa dengan orang tua status sosial ekonomi rendah relatif memiliki prestasi belajar ekonomi yang rendah pula. 2) Terdapat pengaruh signifikan status ekonomi terhadap konsumsi siswa. Semakin tinggi status sosial ekonomi orang tua, maka semakin tinggi pula tingkat rasionalitas siswa dalam berkonsumsi. Siswa cenderung terdorong untuk membeli barang-barang yang sedang trend untuk fungsi aktualisasi diri, dan tidak mementingkan bagaimana fungsi dan manfaat barang yang akan dikonsumsi. 3) Terdapat pengaruh signifikan prestasi belajar terhadap konsumsi siswa. Prestasi belajar yang dicapai oleh siswa tidak hanya nilai pelajaran ekonomi, melainkan juga berupa adanya perubahan sikap dan tingkah laku. Fakta dari penelitian ini menunjukkan bahwa siswa dengan prestasi belajar ekonomi yang tinggi atau memiliki kemampuan kognitif yang baik secara psikomotor juga memiliki kemampuan yang baik pula.

\section{DAFTAR RUJUKAN}

Amaldoss, Wilfred, 2002. An Analysis of the Impact of Social Factors on Purchase Behavior. Review of Marketing Science Working Papers Volume 2, Issue 12002 Article 4 pp. 125-127

Chaney, David, 2003. Lifestyles: Sebuah Pengantar Komprehensif. Yogyakarta: Jalasutra.

Chang, Wei-Lung, 2008. Influence of Family Communication Structure and Vanity Trait on Consumption Behaviour: A Case Study of Adolescent 
Students in Taiwan. Journal of American Academy of Business, Cambridge. Hollywood, March 2008, 43, 170.

Engweiler, L. A., 2005. The influence of socioeconomic status on academic achievement. Paper presented at first annual symposium graduate research and scholarly projects, April 22, Wichita State University, USA.

Haryono, A., 2008. Pengaruh Proses Pembelajaran, Penilaian Hasil Belajar dan Status Sosial Ekonomi terhadap Tingkat Economic Literacy Siswa SMA di Kota Malang. Disertasi. Malang. PPs UM.

Kotler, P \& Amstrong, G., 2012. Principle of Marketing. $14^{\text {th }}$ edition. New Jersey: Prentice-Hall. Inc.

Mehmood, Tariq, 2011. Effects of Socioeconomic Status on Students Achievement. International Journal of Sosial Sciences and Education, Volume: 1 Issue: 2 April 2011.

Rifa'I Rc, Achmad \& Catharina Tri Anni, 2006. Psikologi Pendidikan. Semarang: UNNES Press.

Schiffman, L.G \& Kanuk, L.L., 2008. Perilaku Konsumen. Edisi ke-7. Jakarta: PT. Indeks.

Sitorus, M, 2000. Sosiologi. Bandung: Cahaya Budi.

Soekanto, Soerjono, 2003. Sosiologi Suatu Pengantar. Jakarta: PT Raja Grafindo Persada.

Supriya, 2009. Pendidikan IPS. Bandung: PT. Remaja Rosdakarya.

Suryabrata, 2006. Psikologi Pendidikan. Jakarta: PT. Raja Grafindo Persada.

Wells, W. D., Prensky, D. 2008. Consumer Behaviour. New York: John Wiley \& Sons, Inc. 